\title{
THOSE WHO OFFSHORE AND THOSE WHO DON'T: A COMPARATIVE EXAMINATION OF EXECUTIVE PERSPECTIVES ON IT STRATEGY
}

\author{
Mark P. Sena, Xavier University, sena@xavier.edu \\ James A. Sena, CalPoly San Luis Obispo, jsena@calpoly.edu \\ Gerald Braun, Xavier University, braun@xavier.edu
}

\begin{abstract}
This paper reveals insights from 245 interviews to compare the perspectives of executives in organizations who practice IT offshoring with those of executives whose organizations do not offshore. The principle findings of the study reveal three conclusions: 1) organizations that offshore are not statistically different than those who do not regarding the extent to which they feel that IT is an area that is used to differentiate themselves from competitors; 2) organizations that offshore are more likely to agree that they have effective methods to measure and assess IT investments than organizations that do not offshore; and 3) organizations that offshore are less likely than organizations that do not offshore to agree that the ROI of past projects has generally been positive.
\end{abstract}

\section{INTRODUCTION}

Offshore outsourcing of IT development has become a controversial topic due to the potential loss of white collar jobs and fears about the long term impact that offshoring could have on the economy, the nation's ability to develop innovations in technology, security concerns, and other issues. Much has been written about the controversy surrounding offshoring as well as more instructive articles regarding the practice of implementing and operating offshore programs. However, little research has been done to examine the differences between organizations that embrace offshore as compared to those who do not.

Perspectives on whether investing in IT is a viable means of gaining competitive advantage can be a matter of debate. While some subscribe to the theory that IT is becoming a commodity due to the prevalence of outsourcing, packaged software, and ability to acquire expertise equally across firms [3], others realize that while these trends change the nature of IT management, they understand that equal access to IT resources does not necessarily result in equal success of IT investments (e.g., the variation in success of ERP implementations). As a field, IT has had mixed results on the perceived success or failure of IT investments [8]. Until recently, most companies did not have proven methods to evaluate potential IT investments and measure their results [1]. The practice of offshoring can play a factor on these issues as organizations may be more (or less) reluctant to embrace offshoring based on their perceptions of past projects. Due to the requirements of coordinating and monitoring offshoring partnerships, offshoring may also impact the expansion of organizational practices for measuring and evaluating IT investments.

This study examines the perspectives of executives on the strategic IT issues listed above and compares them between organizations that offshore and those who do not offshore. While this is not a comprehensive review of the differences between offshoring organizations and those who do not offshore, the findings reveal some interesting insights upon which further research can be based.

\section{BACKGROUND}

Companies are increasingly outsourcing the development and management of information technology to gain access to specialized skills, costs, staff utilization, recruitment and training, high standards of control and security, and specialized information services [5]. Conversely, there are other arguments and reasons to retain the IT application development in-house - subject matter expertise, confidentiality of business data, vendor risk, ease of development and acceptance of internal adaptation, and the development of internal leading-edge competence.

Offshore outsourcing offers additional challenges for organizations over its domestic counterpart. Although most advice about how to do offshore outsourcing effectively focuses on processes and requirements, successful offshoring goes beyond these fundamental requirements [7]. It is the result of a continuous build up of "social capital" between customer and supplier [13]. Many organizations are engaged in offshore outsourcing of their IT activities in various degrees and for many reasons including cost, shortage of IT talent, quality, and tax incentives. Without a 
thorough assessment of various risks involved in offshore outsourcing of IT activities, however, benefits may be offset by significant losses because of various risk factors and missed opportunities [16]. Some CIOs deferred making sourcing decisions about possible offshoring because they believed that offshoring is a "permanent" choice and the cost advantages of offshoring would diminish.

Outsourcing's value depends on the actions of those who are tasked with making it real [6]. Done well, it saves money and allows an organization to reinvest in high-value activities such as interacting with customers, managing innovation, defining strategic direction and formulating plans [12]. Done poorly, outsourcing can raise costs around the management of sourcing relationships and syncing up processes and can strip an organization of creativity by focusing internal resources on work that lacks innovation [4].

The movement toward IT offshoring has become a political topic due to fears of job loss. Buchholz [2] in his book, "Bringing the Jobs Home" contends that while lecturing to technology executives, he observed the preponderance of the outsourcing wave. The executives explained that they might not be firing Americans, but they were not looking to hire more. Forrester Research [14] states that more than 800,000 white-collar jobs traveled overseas in 2005 and the number will reach 3.3 million by 2015 . Despite these figures, however, employment statistics among most domestic IT job categories remains strong.

Beyond the issue of IT jobs, some question whether the movement toward offshoring suggests further evidence that IT is regarded by executives as a necessary evil whose costs must be minimized rather than viewing IT as a strategic area that can be used to gain a competitive edge. In a hotly debated article, Carr [3] contends that because of the ubiquitous nature of modern IT initiatives, IT is no longer strategically important to the business. Carr states that companies "only gain an edge over rivals by having or doing something that they can't have or do.” He encourages companies to delay IT investments because "studies of corporate IT spending consistently show that greater expenditures rarely translate into superior financial results."

In general, the literature supports the notion that IT initiatives do not necessarily lead to a positive return on investment. A McKinsey Global Institute study [11] on "U.S. Productivity Growth for 1995 to 2000" found a positive correlation between IT investments and productivity in only 6 of 59 industries.
Strassmann [15] contends that his research confirms that "profitability and IT spending are unrelated." Conversely, a poll of 250 senior finance executives [9] indicated a surprising consensus on the ultimate potential of IT. Three-fourths of the respondents considered IT to be strategic and $60 \%$ of those plan to spend more on IT in 2005. However, fewer than half of all respondents believed that IT expenditures achieved the return they had expected. In a 2004 study [10], 51\% of 182 survey respondents increased 2004 budgets from 2003 levels and 43\% of 2005 budgets will be greater than in 2004. Brennan [1] contends that return on IT investments is a primary concern and appropriate measures are necessary to "distinguish fads from substance." He sees the biggest pitfall in IT decision making is embracing a solution without fully understanding the underlying needs.

The movement toward the offshoring of IT began shortly after the dot com bubble and the economic fallout after the 911 terrorist attacks. As a result of declining IT budgets, organizations were held to a higher standard of accountability [1]. While this short term decline in IT investment had a negative impact on some facets of the industry, a positive outcome was the development of new methods for evaluating and measuring IT investments. As a result many companies are now better equipped to examine the value of potential projects before they invest and are better able to track the costs and benefits resulting from IT investments.

\section{RESEARCH QUESTIONS AND METHODOLOGY}

The literature reviewed in the prior section describes the following trends and debates: 1 ) organizations are increasingly utilizing offshore outsourcing to minimize development costs; 2) there is ongoing debate as to whether IT serves as a differentiator among competing firms; 3) there are mixed viewpoints regarding the past ROI performance of IT investments; and 4) there is increasing focus on the measurement and assessment of IT investments.

To investigate the relationship between these issues, we offer the following exploratory hypotheses:

Hypothesis 1: Organizations that offshore IT will not differ from those who do not regarding their view of IT as an area that is used to differentiate themselves from competitors.

Hypothesis 2: Organizations that offshore IT will not differ from those who do not regarding their 
perception that past IT investments have had a positive ROI.

Hypothesis 3: Organizations that offshore IT will not differ from those who do not regarding their perception that they have implemented mechanisms that effectively measure and justify IT expenditures.

To investigate these hypotheses, personal interviews were conducted with 245 senior level executives. Most of the interviews were conducted with executives in a relatively large city in the Midwestern United States. Thus, the findings in this study may be limited if there are regional differences in perspectives.

The executives were asked to comment on a series of questions about IT strategy and provide a rating on Likert scale (5=strongly agree, $3=$ =neutral, $1=$ strongly disagree). The questions included the following which are relevant to this study:

- We are looking increasingly to reduce costs by using offshore IT outsourcing

- Our use of IT helps differentiate us from our competitors

- Most of our investments in IT have resulted in positive return on investment

- We have implemented mechanisms that effectively measure and justify IT expenditures

\section{ANALYSIS AND FINDINGS}

Two basic statistical tests, a Pearson Correlation and a t-test for equality of means, were conducted to examine the hypotheses. The t-test for equality of means was formed by dividing the sample into two groups. Those who "disagreed" or "strongly disagreed" with the question that they are looking to reduce cost by using offshore IT were placed in one group while the remaining subjects were placed in another. The sample included 127 executives who fell into the "Do Not Offshore" group while 115 fell into the "Offshore" group. The 30 respondents who answered "neutral" to the question were lumped in the offshore group. The t-test for equality of means was also conducted without the neutral responses in the data set, and the findings were very similar for each of the hypotheses.

As shown in Table 1, there is not a statistically significant correlation between IT offshoring and the use of IT as a competitive differentiator. The test of means actually shows a slightly higher response among the offshoring group, though the difference is not statistically significant. Thus, there is no evidence to reject Hypothesis 1. This indicates that organizations that offshore are not rejecting the notion that IT can be used for competitive advantage. In fact, anecdotes from interviews support the notion that organizations that offshore also compete on the basis of IT.

This is a potential important finding. Those who subscribe to the opinions set forth by Carr in IT Doesn't Matter [3] may view the movement toward offshoring as further evidence that that IT is declining in strategic importance. The results of this study would not support this view as there is no statistical relationship between offshoring and decreased perceived importance of IT as a basis for competition.

Table 1: Correlation Between Offshoring of IT and Strategic IT Perspectives

\begin{tabular}{|l|l|}
\hline & $\begin{array}{l}\text { We are looking increasingly to reduce costs by } \\
\text { using offshore IT outsourcing }\end{array}$ \\
\hline $\begin{array}{l}\text { Our use of IT helps differentiate us from our } \\
\text { competitors }\end{array}$ & $\mathrm{r}=.062(\mathrm{p}=.335)$ \\
\hline $\begin{array}{l}\text { In the past, most of our investments in IT have resulted } \\
\text { in positive return on investment }\end{array}$ & $\mathrm{r}=-.115(\mathrm{p}=.074)$ \\
\hline $\begin{array}{l}\text { We have implemented mechanisms that effectively } \\
\text { measure and justify IT expenditures }\end{array}$ & $\mathrm{r}=.171(\mathrm{p}=.007)$ \\
\hline
\end{tabular}


Table 2: Test of Means; Organizations that Offshore vs. Those Who Do Not Offshore

\begin{tabular}{|l|c|c|c|}
\hline & Offshore & $\begin{array}{c}\text { Do Not } \\
\text { Offshore }\end{array}$ & $\begin{array}{c}\text { T-test of } \\
\text { Difference }\end{array}$ \\
\hline Our use of IT helps differentiate us from our competitors & 3.97 & 3.91 & $\mathbf{t}=.440$ (p=.66) \\
\hline $\begin{array}{l}\text { In the past, most of our investments in IT have resulted } \\
\text { in positive return on investment }\end{array}$ & 3.58 & 3.81 & $\mathbf{t}=1.94(\mathrm{p}=.05)$ \\
\hline $\begin{array}{l}\text { We have implemented mechanisms that effectively } \\
\text { measure and justify IT expenditures }\end{array}$ & 3.67 & 3.34 & $\mathbf{t}=2.15(\mathrm{p}=.03)$ \\
\hline
\end{tabular}

The relationship between perspectives on ROI of IT investments and IT offshoring remains somewhat inconclusive. The negative correlation coefficient in Table 1 did not meet the .05 standard that some view as the cut off to conclude that there is a statistically significant relationship. As shown in Table 2 the test of means showed a moderate difference in viewpoints between executives from organizations who offshore as compared with those who do not offshore. Whether the relative lack of success in ROI in past investments is a factor in the acceptance of offshoring initiatives would be an interesting subject for future investigations.

An important extension to this study would be to further investigate the reasons (beyond cost savings) why organizations embark on offshoring relationships and the extent to which perceptions on ROI of past projects are considered in making such decisions.

Lastly, the results in both tables indicate that there is a statistical difference in perceptions surrounding organizational mechanisms to measure and justify IT investments. Thus, the data would suggest that there is ample evidence to reject hypothesis 3 .

This finding could lead to a conclusion that organizations that do not have proven methods for tracking IT investments and monitoring expenditures would likely not be good candidates for offshoring or that size plays a role in offshoring decisions as larger organizations are inherently more likely to have advanced techniques for measuring IT investments. Future studies could focus on the nature of metrics for monitoring offshore relationships and the impact that improved evaluation of IT investments has on the organization's long term success of IT projects.

\section{CONCLUSIONS}

The findings of this study reflect the views of 245 executive interviews and suggest that organizations that offshore still value IT as an important source of differentiation but their willingness to embrace offshoring could stem, to a mild degree, on the relative lack of success of past IT investments. Or conversely, organizations that do not offshore may be reticent to do so due to the value they perceive on the ROI of past IT investments.

In order to be successful in offshoring, literature suggests that provisions need to be made to govern and monitor the actions of offshoring activities. This study reveals that the relative level of effectiveness that organizations that offshore perceive in their ability to measure and justify IT expenditures is greater than those in organizations that do not offshore.

With the controversy surrounding IT offshoring and the mixed success that some organizations have experienced in the initial wave of offshoring, it is important for academic scholars to study IT offshoring with an unbiased view and monitor the trend closely by gathering the viewpoints of key decision makers. Future research in this area could focus on a more comprehensive set of items using proven empirical instruments.

While this study only touches on a few aspects of the multitude of potential strategic issues that could be examined, it serves as a starting point for comparing the potential differences and similarities between organizations that offshore and those who do not.

\section{REFERENCES}

1. Brennan, J. (2002), CEO: Show Me the Value. CIO.com, May 2002. http://www.cio.com/article/31044/CEO_Show_ Me_the_Value

2. Buchholz, T. (2004). Bringing the Jobs Home. New York, Sentinel. 
3. Carr, N.G. (2003). IT doesn't matter. Harvard Business Review, 81(5), 41-49.

4. Cramm, Susan (2006) A Good Offense Is a Good Defense CIO. Oct 1, 2006.Vol.20, Iss. 1; pg. 1

5. Downing, Charles, Field, Joy, and Ritzman, Larry, (2003). The Value of Outsourcing: A Field Study, Information Systems Management, Winter 2003.

6. Engardio, P. (2006). The Future of Outsourcing. Business Week: 50-58.

7. Gottfredson, M., Puryear, Rudy and Phillips, and Stephen (2005). Strategic Sourcing, Harvard Business Review.

8. IT Cortex. Failure Rate: Summary of Statistics on IT Project Failure Rate. http://www.itcortex.com/Stat_Failure_Rate.htm

9. Leibs, S. (2004). One way or another: CFOs agree on the value of IT but disagree on how to measure and manage it. CFO, 20(15), 18-23.
10. Luftman, J. (2004). Key issues for IT executives. MIS Quarterly Executive, 4(2), 269-285.

11. McKinsey \& Company (2001). US Productivity Growth, 1995-2000. McKinsey Global Institute.

12. O'Reilly, C. and T., Michael (2004).The Ambidextrous Organization. Harvard Business Review.

13. Overby, Stephanie (2007) Secrets of Offshoring Success ; CIO. Feb 1, 2007.Vol.20, Iss. 8; pg. 1

14. Shinal, J. (2004) Jobs Flying Faster From U.S., San Francisco Chronicle. May 18. 2004.

15. Strassmann, P. A. (2003). Letters to the editor, Does IT matter? An HBR Debate. Harvard Business Review, 81(7), 7-9

16. Tafti. Mohammed H.A. (2005) Risks factors associated with offshore IT outsourcing Industrial Management \& Data Systems_Vol. 105 No. 5, 2005 pp. 549-560 